Erkenne Dich selbst - Anthropologische Perspektiven I 


\section{Hegel-Jahrbuch 2018}

Herausgegeben von

Brady Bowman, Myriam Gerhard, Jure Zovko

Begründet von

Wilhelm Raimund Beyer ( $t$ ) 


\section{Erkenne Dich selbst}

- Anthropologische

Perspektiven I

Herausgegeben von

Brady Bowman, Myriam Gerhard, Jure Zovko

in Verbindung mit

Birgit Sandkaulen

\section{DE GRUYTER}


ISSN 0073-1579

Library of Congress Cataloging-in-Publication Data

A CIP catalog record for this book has been applied for at the Library of Congress.

Bibliografische Information der Deutschen Nationalbibliothek

Die Deutsche Nationalbibliothek verzeichnet diese Publikation in der Deutschen Nationalbibliografie; detaillierte bibliografische Daten sind im Internet über http://dnb.dnb.de abrufbar.

(C) 2019 Walter de Gruyter GmbH, Berlin/Boston

Satz: Veit Friemert, Berlin

Druck und Bindung: $\mathrm{CPI}$ books $\mathrm{GmbH}$, Leck

www.degruyter.com 


\section{Inhaltsverzeichnis}

Vorwort der Herausgeber — 11

Birgit Sandkaulen

Vorwort - 13

Walter Jaeschke, Bochum

De nuptiis philologiae et philosophiae

Zum Abschluss der Ausgabe Hegel: Gesammelte Werke - 15

\section{Erkenne Dich selbst - Vernunft und Selbst}

Ludwig Siep, Münster

Erfahrung des Bewusstseins oder Vernunft in der Geschichte? - 24

Claudia Bickmann †, Köln

Sein und Selbst-Sein.

Hegels Idee der Selbsterkenntnis zwischen Sich-Bestimmen und Sich-Setzen — 34

Marc Nicolas Sommer, Basel

Die Selbsterkenntnis des Verstandes -40

Sergey Peruanskiy, Moscow

Anthropological Aspects of Hegel's Doctrine on the Concept - 46

Juan Serey, Viña del Mar

The Concept, Negativity, and the „I“.

On some Difficulties at the Beginning of th Subjective Logic - 51

Edgar Maraguat, Valencia

On the Logical Idea of Objective Concept -56

Amrit Mandzak-Heer, Philadelphia

Cognizing Cognition's Living Conditions.

Anthropological Implications in Hegel's Logic - 60

Achim Wamßler, Berlin

Der Begriff Heimat bei Hegel. Logische und sittliche Perspektiven — 65

Silviya Kristeva, Blagoevgrad

The Subjective Relation as a Moment of Determination in Hegel's Science of Logic - 70

Andrei Chitu, Tübingen

Hegels Theorie der Modalitäten und ihre realphilosophische Bedeutung — 76

Antonios Kalatzis, Jerusalem

Intelligenz und Logik. Hegels Begriff des „Denkens“ zwischen „wissenschaftlicher Logik“, Philosophie des subjektiven und des objektiven Geistes - $\mathbf{8 0}$

Armando Manchisi, Padova, Münster

Die Idee als „sich wissende Wahrheit“ — 87 
Noam Cohen, Be'er Sheva

Logic and Morality. Contradiction, Good and Evil — 93

Norman Schultz, Pittsburgh

Logic and Time - The Diamond Net and the Movement of Spirit — 98

Sander Wilkens, Trier

Die Antonymie zwischen Logik, Geschichtsphilosophie und Anthropologie — 102

Lars Heckenroth, Köln

Die Substanz als Subjekt. Genese einer anthropologischen Grundbestimmung - 107

Lorenzo Sala, Pisa

Is Being Thought? On What Spirit's Systematic Role can Teach Us

about Hegel's Identity of Thought and Being - 112

Toru Ikeda, Chiba

Das verdoppelte Spekulative im Prozess der Unendlichkeit.

Zur Präzisierung des hegelschen Idealismus in der Umschreibung von

Wissenschaft der Logik und Enzyklopädie — 117

Stefan Köchel, Graz, Klagenfurt

Hegels anthropologischer Gesichtspunkt. Eine Annäherung —123

Giovanna Miolli, Padua

Hegel's Theory of Truth as a Theory of Self-Knowledge - 128

Lucas Pétuaud-Létang, Bordeaux

Der Geist als sich selbst erkennende Wahrheit — 134

Renate Wahsner, Berlin

Hegels Auseinanderlegen des Konkreten und dessen Aufhebung — 139

Justus Schollmeyer, Berlin

Dialektische Theorien zur Lösung von Erfindungsaufgaben —144

Annette Sell, Bochum

Der Mensch im Vorbegriff — 150

Thomas Hanke, Frankfurt am Main

Menschliches Denken. Über anthropologische Aspekte

in Hegels Logik-Vorlesungen - 155

Florian Ganzinger, Leipzig

Das denkende Lebewesen und der Entschluss rein zu denken — 161

Ludwig Krüger, Hagen und Tutzing

Der Mensch als logische Herausforderung. Anthropologie als (Formal)Logikkritik und Einheit der Vernunft — 167

Zhili Xiong, Heidelberg

Spekulative Logik als die Methodologie der philosophischen Anthropologie Hegels — 172 
Roland Carspecken, Pittsburgh

Community and Thought. Hegel on Human Nature and the History of Philosophy — 177 Joris Spigt, Leuven

The Unity of Oppositions: Reason's Self-Knowledge — 182

Pedro Sepúlveda, Hagen

Die Einheit bei Hegel. Eine Phänomenologie des Begriffs in der spekulativen Phase

\section{Anthropologie - Die Seele}

Charles Larmore, Providence

Inwiefern soll Selbsterkenntnis philosophisch wichtig sein? —192

Angelica Nuzzo, New York

„Consciousness awakens in the soul“. Anthropology within the Systematic of

Hegel's Theory of Spirit — 201

Stefan Mertens, Potsdam

Worin bestehen eigentlich Hegels anthropologische Perspektiven? 209

Loughlin Gleeson, Sydney

An Evaluative Essentialist and Holistic Reading of

Hegelian Concrete Freedom in Outline: Contra Pippin — 216

Önay Sözer, Istanbul

Auf dem Weg der Selbsterkenntnis. Erzitterung als Anfang der Subjektivität

im Sinne von „Selbst“_ 226

Maik Puzić, Siegen

Die spekulative Dimension der Anthropologie und die Rolle der Gewohnheit — 231

Riccardo Martinelli, Trieste

Hegel on Character: Encyclopedia § $395-237$

Stefania Achella, Chieti

Die Subjektivität und das Unbewusste — 243

Werner Ludwig Euler, Florianópolis

Hegels Entwurf psychischer Krankheit in der Anthropologie der Enzyklopädie - 249

Dan Tenne, Tel Aviv

Man and the Science of Man in Kant and Hegel — 255

Filippo Bortolato, Padova

The Role of Aristotle's De anima in the Encyclopaedic Anthropology — 261

Christian Hofmann, Hagen

Weltseele oder passiver nous? Zur allgemeinen Substanz des subjektiven Geistes — 267

Ulrich Fritz Wodarzik, Lampertheim

Hegels Geistmetaphysik mit Blick auf Plotins Seelenproblematik — 272 
Jean-Marie Lardic, Nantes

Que connaît l'anthropologie? — 279

Claude Thérien, Trois-Rivières

Contribution à l'esthétique des sensations.

Un parallèle entre l'idée d'une „physiologie psychique“

chez Hegel et la notion de „corps de l'esprit“ chez Valéry — 284

Antón Barba-Kay, Washington DC

Hegel on Sleep and Walking — 290

Luca Corti, Bonn

Prolegomena für eine heterodoxe Lektüre von Hegels Anthropologie -295

\section{Phänomenologie und Psychologie}

Anton Ivanenko, Sankt Petersburg

Der Status der Phänomenologie in den philosophischen Systemen von

Fichte und Hegel -300

Markus Gante, Bochum

Subjektivität und Leiblichkeit bei Hegel und Fichte — 303

Héctor Ferreiro, Buenos Aires

Der praktische Geist ist der wirkliche Geist. Zu Hegels Antirepräsentationalismus — 310

Brendan Theunissen, Berlin

Ist Hegels Anthropologie eine deskriptive oder eine revisionäre Theorie?

Plädoyer für eine revisionäre Lesart — 316

Xabier Insausti, Baskenland

Ein Wir, das Ich, und ein Ich, das Wir ist - 322

Ryu Okazaki, Berlin

Die Sache selbst als Subjekt in Hegels Phänomenologie des Geistes _ 329

Stefan Kühnen, Oldenburg

Zur „anthropologischen“ Grundlage der Bewegung des Anerkennens — 334

Misa Sanada, Heidelberg

Die philosophische Anthropologie und die moralische Funktion des Gewissens

in der Philosophie Hegels - 340

María del Carmen Paredes-Martin, Salamanca

The Limits and Role of „Verstand“ _ 345

Serena Feloj, Pavia

Natural Intention vs. Objective Teleology. The Notion of Force in the

Preface to the Phaenomenology of Spirit - 350 
François Ottmann, Paris

Geist und Buchstabe.

Friedrich Schlegels Prolegomena zu Hegels Theorie des Geistes — 356

Denis Kaidalov, Warsaw

Hegel's Philosophy of Mind and its Reception by Vygotsky — 361

Valentin Kanawrow, Blagoevgrad

Das Sein des Geistes ist /k/ein Knochen: Hegel und Lavater — 365

Holger Hagen, Hannover

,Menschenkenntnis' und ,Selbsterkenntnis' in der modernen Gesellschaft:

Reflexionen von Freiheit und Verdinglichung — 370 


\section{Hegel on Character: Encyclopedia § 395}

\section{Introductory remarks}

After the initial sections of Philosophy of Subjective Spirit, in $\S 395$ of the Encyclopedia of the Philosophical Sciences in Outlines Hegel explains how the natural soul is eventually "singularized into the individual subject“. The individual subject occurs here with a merely anthropological meaning, that is, qua „singularization of a natural determinateness“. Still, a „firm determinateness" is already enforced at this stage, in terms of an unprecedented emergence of an embryonic form of individuality over the definitely over-individual previous moments of the natural soul (§§ 392-394). Besides its intrinsic interest, § 395 offers important insights into Hegel's concept of character, considered in several other passages of Encyclopedia as well, no less than in important works like Phenomenology of Spirit, Aesthetics, Philosophy of Right. In this essay I address Hegel's treatment of character within the boundaries of $\S 395$ of Encyclopedia. As a first step, the text of $\S 395$ is considered together with the commentaries given by Hegel in his lectures ( $\S 2$ ). Secondly, attention is drawn to Kant's treatment of the same subject matter in Anthropology from a pragmatic point of view (§3). The conclusive paragraph addresses some philosophical difficulties regarding character and Kant's importance with reference to Hegel's Anthropology (§4).

\section{The anthropological concept of character}

The paragraph under consideration is situated in the first part (Anthropology. The soul) of Philosophy of Subjective Spirit. The initial chapter, entitled The natural soul, begins with a subheading (Natural qualities) which consists of three moments: 1) Natural soul (§ 392); 2) Racial variety (§§ 393-394); and 3) The individual subject (§ 395). The text reads:

The soul is 3) singularized into the individual subject. At this juncture however, this subjectivity is considered only as the singularization of a natural determinateness. Its mode of being is the special temperament, talent, character, physiognomy and other dispositions and idiosyncrasies, of families or singular individuals. ${ }^{1}$

1 G. W. F. Hegel, Hegel's Philosophy of Subjective Spirit, 3 vols., Dordrecht/Boston 1978, translated by M. J. Petry, vol. 2, 83 (GW 20, 297). I refer to Hegel's works (and lectures, when available) according to the edition by the Nordrhein-Westfälischen Akademie der Wissenschaften und der Künste: Gesammelte Werke, Hamburg 1968 ss., abbreviated as GW, followed by volume number and page. For further commentary on $\S 395$ see H. Drüe, A. Gethmann-Siefert et al., Hegels Enzyklopädie der philosophischen Wissenschaften (1830). Ein Kommentar zum Systemgrundriß, Frankfurt am Main 2000, 220-221; D. Stederoth, Hegels Philosophie des subjektiven Geistes: Ein komparatorischer Kommentar, Berlin 2001, 131-134; M. Inwood, A Commentary on Hegel's Philosophy of Mind, Oxford/New York 2007, 337-339. See also A. Nuzzo, „Anthropology, Geist, and the Soul-Body Relation. The Systematic Beginning of Hegel's Philosophy,“ in: Essays on Hegel's Philosophy of Subjective Spirit, edited by D. S. Stern, Albany 2013, 1-17. 
From the first edition (1817, as $§ 314)$ to the third (1830) of Hegel's Encyclopedia the paragraph undergoes little variation. ${ }^{2}$ Hegel also offered many explanatory remarks in his lectures. Let us start from the Additions published by Ludwig Boumann in his 1845 edition of Philosophy of Subjective Spirit. The long Addition to $§ 395$ singles out three elements in the soul's path toward subjective individuality: ,[t] These are distinguished according to the determinations of what is natural [Naturell], of temperament and of character. " ${ }^{3}$ The text addresses the nature and the interlacement between ,what is natural," temperament and character.

The term Naturell, nowadays obsolete, was able to capture from the early XVIIIth century until Hegel's time a whole range of respectable philosophical problems. ${ }^{4}$ In the Addition, we are told that Naturell is made up of „talent and genius“. For Hegel, Naturell is the complex of all the „natural endowments,“ as „distinct from whatever the person has become by means of his own activity“. These endowments should be schooled in accordance with ,general accepted procedures" if they are not to be „wrecked, run to ruin, or degenerate into spurious originality“. ${ }^{5}$ Without schooling, it is impossible for talent and genius to develop properly. Genius should not be considered superior to human reason. The differences between these dispositions have no relevance with regard to morality or to the doctrine of virtue, but rather „would have to be considered only in what one may call a natural history of spirit“. ${ }^{6}$

As Hegel honestly avows, „it is difficult to say what one means by temperament“ since it has no „external involvement“: it reveals itself neither in action nor in passion. Temperament is „the completely universal mode and manner in which the individual is active in objectivizing itself by comporting itself within actuality". ${ }^{7}$ Hegel also sketches a sort of history of temperament. In the course of time, superior cultures have become less and less indulgent with the excesses of temperament. For instance, the one-sided characters of early comedies, such as „the completely scatter-brained, the ludicrously absent-minded, the tight-fisted skinflint," at the later stages of cultural development tend to disappear. Similarly, unilateral temperaments hardly characterize real individuals. Different temperaments dwell within the same person, in variable proportions according to the individual under analysis. Quoting Kant's observations on temperaments in Anthropology from a pragmatic point of view, Hegel comments: „whereas the temperaments are presented as being distinct, in the individual itself they are more or less united". 8

Finally, Hegel deals with character. He distinguishes a formal aspect, that is, „the energy with which the person pursues his purposes and interests regardless of distraction, and preserves self-consistency in all that he does, “ from the general content of one's will. The greatness of characters reveals itself in „the accomplishment of great designs“.9

For Hegel Naturell, temperament and character form a fixed triadic structure, whose order cannot be subverted.

We have now delineated the three forms of the qualitative natural determinateness of the individual soul i. e. what is natural, temperament and character. In this connection we have however still to indicate the rational

2 G. W. F. Hegel, Enzyklopädie der philosophischen Wissenschaften im Grundrisse, GW 13, 186 (ed. 1817), where the soul is referred to as the „überhaupt an sich der Begriff“ and no mention is made to „talent“ and „idiosyncrasies.“ GW 19, 297 (ed. 1827) presents a minor variation.

3 Hegel, Philosophy of Subjective Spirit, vol. 2, 85.

4 J. G. Walch, Philosophisches Lexicon, Leipzig 1726, 1860-1876.

5 Hegel, Philosophy of Subjective Spirit, vol. 2, 85.

6 Hegel, Philosophy of Subjective Spirit, vol. 2, 87.

7 Ibid.

8 Hegel, Philosophy of Subjective Spirit, vol. 2, 89.

9 Hegel, Philosophy of Subjective Spirit, vol. 2, 91. Most of these remarks concerning character can be found in Kant's Anthropology. I. Fetscher, Hegels Lehre vom Menschen, Stuttgart/Bad Cannstatt 1970, 42, considers „,surprising“ that Hegel deals with character already at this early stage of Encyclopedia. 
necessity of there being precisely these three forms of this determinateness and no others, and of their being considered in the order we have followed. (Hegel, Philosophy of Subjective Spirit, vol. 2, 93)

Yet Hegel himself did not always follow this order. As for the transcription of his lectures (Nachschriften), Hotho (1822) mentions talent, temperament and character; Griesheim (1825) includes a non-systematically sequenced reference to Naturell, temperament, talent and character; Stolzenberg (1827/28) focuses upon temperament; Erdmann and Walter deal with temperament, talent and character. ${ }^{10}$ Unfortunately, it is not easy to situate Boumann's Additions within this timeline. Boumann had several sources at his disposal, many of which are now lost: besides two notebooks of Hegel's (1817 and 1820) he consulted transcriptions taken by himself and others, of the years 1825, 1828 and 1830. However, although expressed in slightly different terms, Hegel's core argument about the individual subject remained constant over time. „Character“ is almost invariably the culminating element, along with temperament and a third element, referred to either as „talent“ or as „what is natural,“ which are indeed closely related to each other (as we have seen, talent is a part of Naturell together with genius). Despite these variations, therefore, Boumann's Addition to $\S 395$ is essentially consistent with the remaining sources and can be considered representative of Hegel's thought. ${ }^{11}$

How did Hegel argue for the „rational necessity“ of the presented triad? The immediacy of the Naturell echoes the beginnings of Logic: it is the mere being of the individual subject, without any development: ,in what is natural the predominant form of the qualitative natural determinateness of the individual soul is that of mere being, of a firm immediacy, of that which has an inner differentiation relating to the difference present outside it“. By contrast, in temperament these immediacy and firmness are lost in favour of a multiplicity of dispositions, variously interacting with each other. At this stage, ,the natural determinateness loses this firmness of shape, for it is either one talent that dominates the individual exclusively, or several that subsist in it side by side without disturbing or influencing one another". ${ }^{12}$

All of these elements sublate in proper character, where

we find the firmness of what is natural, together with its prevailing relation outwards, united with the changeableness of general temperamental moods and the predominant intro-reflectedness of the soul which these entail. Firmness of character is developed by means of the will; it is not so innate as that which is natural, and lacks the immediacy of natural firmness. Character consists of something more than a proportionable melange of the various temperaments. (Hegel, Philosophy of Subjective Spirit, vol. 2, 95)

Hegel is adamant in assigning an important dialectic function to character. The human being's instinctual and temperamental patrimony is not morally disapproved of, or simply denied, but rather it is dialectically overcome via the affirmation of character. The anthropological treatment of character allows Hegel to link the lowest layers of human personality with the higher ones, as it is demonstrated by the further emergence of the concept of character in the free Spirit. Hegel explains:

Nevertheless, it cannot be denied that it has a natural basis - that certain people are by nature more disposed to strength of character than others. It is on account of this that we have made mention of character in dealing with anthropology. It is however in the sphere of free spirit that character first unfolds to its full extent. (Hegel, Philosophy of Subjective Spirit, vol. 2, 95).

10 G. W. F. Hegel, Vorlesungen über die Philosophie des subjektiven Geistes, GW25/1 39-41, 241-246; GW25/2, 616-619. See also G. W. F. Hegel, Lectures on the Philosophy of Spirit 1827-1828, translated by R. R. Williams, Oxford, New York 2007, 94-95. As previously shown, from 1817 to 1827 in the text of $\S 395$ a certain amount of variation already occurs. 11 On the occasional inconsistency of Boumann's Additions with other sources, see Williams' introduction in Hegel, Lectures on the Philosophy of Spirit 1827-1828, 4.

12 Hegel, Philosophy of Subjective Spirit, vol. 2, 93. 
In the words of the Addition to $\S 482$, that is, in the Free spirit at the very end of Philosophy of Subjective Spirit, the „feeling of freedom is no longer an impulse demanding its satisfaction, but character, - spiritual consciousness which has shed impulse in assuming being “. ${ }^{13}$

\section{Hegel's and Kant's Anthropologies}

A study of Hegel's sources raises interesting critical issues. In an explanatory note to his edition of Philosophy of Subjective Spirit, J. M. Petry considers Hegel's usage of Naturell in „substantial agreement with the accepted usage of the time“. To provide an example, Petry quotes from Die Anthropologie als Wissenschaft by Joseph Hillebrand. ${ }^{14}$ By gathering and listing many texts of the time concerning anthropology, and by showing that several of Hegel's arguments on this topic owe to this literature, Petry has undoubtedly rendered an excellent service to scholars. However, despite his acknowledgement of the role of Kant's Anthropology in this field, and his reference to Kant together with Hillebrand in this respect, in some cases Petry seems to underestimate Kant's role as Hegel's source.

The case of $\S 395$ is exemplary. In Petry’s view, by treating Naturell ,as the immediate antecedent of temperament and character, Hegel does manage to give a preciser meaning and clearer significance to what is under consideration" ${ }^{15}$ But this is exactly what Kant did. In his Anthropology from a pragmatic point of view Kant subdivides ,what is characteristic [das Charakteristische]“ of the human being into: „(a) his natural aptitude [Naturell] [...], (b) his temperament or sensibility, and (c) his character purely and simply, or way of thinking“. ${ }^{16}$ Whereas in this respect there is no evidence of Hegel's acquaintance with Hillebrand, in the Addition to $\S 395$ Hegel specifically refers to Kant's Anthropology when speaking of the temperaments. Moreover, in the section quoted by Petry (,Von der Characteristik des Persönlichen“), Hillebrand does little more than commenting upon the correspondent part of Kant's Anthropology, duly quoted as a source. Therefore, there is no way to eschew the conclusion that the source for Hegel's sequence of Naturell, temperament and character was Kant's Anthropology. As in many other cases, Hegel is here in „substantial agreement“ with minor writings of his time, since both Hegel and the ,anthropologists“ (in the contextual meaning) borrowed from Kant's book of 1798.

That Kant's Anthropology should put together Naturell, temperament and character is remarkable, since elsewhere Kant articulates character into two, rather than into three elements. In a famous passage of Critique of pure reason, Kant distinguishes between empirical and intelligible character: „the first one could call the character“ of a certain thing „,in appearance, “ the second „its character as a thing in itself“. A person has both a sensible character - that is, the mode of sense (Sinnesart) - and a moral character or „mode of thought“ (Denkungsart). ${ }^{17}$ The human beings, endowed with an intelligible character, can thus act as free agents without any violation of the natural laws.

As previously shown, in Kant's Anthropology a new element - the Naturell - integrates the critical dichotomy of Sinnesart (corresponding to temperament) and Denkungsart (corresponding to moral character). Explaining when and why Kant introduced this new element into his Anthropology would take us too far. ${ }^{18}$ Suffice to introduce a short reference to Kant's sources.

13 Hegel, Philosophy of Subjective Spirit, vol. 3, 269 (emphasis mine).

14 J. Hillebrand, Die Anthropologie als Wissenschaft, Mainz 1822, 385-396.

15 Petry in Hegel, Philosophy of Subjective Spirit, vol. 2, 464.

16 I. Kant, Anthropology from a Pragmatic Point of View, Cambridge/New York 2006, translated by R. R. Louden, 384.

17 I. Kant, Critique of pure reason, Cambridge/New York 1999, translated by P. Guyer and A. Wood, 542 (B 567).

18 I have dealt with this theme at the Kant-Kongress of September 2015 in Vienna: R. Martinelli, Natural aptitude (Naturell) in Kant's doctrine of character, which will appear in the proceedings. 
Most probably, Kant borrows the triad from Georg Friedrich Meier's handbook of Logic, which he used as a textbook for his lectures in Königsberg. Meier supplemented his logic with a final section concerning the so-called logica naturalis (as opposed to the logica artificialis), consisting of an analysis of the „character“ of the erudite. The character of a scholar, Meier claims, consists of three elements: the „erudite nature“ (gelehrtes Naturell), exercise, and zeal. ${ }^{19}$ Although the subdivision does not totally cover Kant's scheme, the Naturell clearly opens the list (but temperament recurs in Meier's argument as well). Being a good scholar requires a natural disposition: without that, all efforts are in vain. At the same time, this Naturell alone, without schooling would bring about no result (as later maintained by Hegel too). What Kant did was to generalize this scheme from natural logic to anthropology where, instead of the erudite's, the human character in general is at stake.

\section{Conclusion}

In a sense, Kant's critical dichotomy of sensible and intelligible character offers a tempting way to deal with character: there are two separate spheres, with no intersection. This picture helps preserve the purity of the moral decision, uninfluenced by the impulses. Yet it leaves unanswered an amount of anthropological issues. It is for this reason that Kant borrows Meier's Naturell in his Anthropology: the instinctual sphere somehow should belong to the human character. To be sure, Kant always allows the individual's character a substantial independence from his passions: the establishment of character is a sort of „explosion, “ a sudden decision to act according to principles, which comes, if ever, at a relatively late age.

Hegel agrees that character „has a natural basis - that certain people are by nature more disposed to strength of character than others". Character points at a high spiritual level, where all impulses are overcome, and yet it stems from a complex of inscrutably opaque inborn dispositions. Hegel cannot accept Kant's critical dichotomy. ${ }^{20}$ Rather, his Anthropology followed Kant's in trying to cope with this set of difficulties by means of a three-layer structure, made up of Naturell, temperament and character. However, Hegel transformed Kant's static structure into a dialectic movement where Naturell and temperament - that is, mono-thematic inwardness and plural outwardness of character traits - sublate into the firm openness of the true character. Kant's anthropological terminology was resumed by Hegel with no variation; but its meaning undergoes a deep modification as a consequence of the general structure of his Philosophy of Subjective Spirit.

The analysis of $\S 395$ suggests some general remarks concerning an ongoing critical debate. As Williams effectively argues, to a certain extent ,the divergence is over the significance of Aristotle and Kant for Hegel's Philosophy of Spirit“. ${ }^{21}$ Such a complex question cannot be addressed in these few conclusive lines. Yet there is little doubt that the numerous recent critical advancements concerning Kant's anthropological writings (including his Lessons on Anthropology) may constitute the highly welcomed vehicles of a renewed appreciation of Kant's Anthropology as an important source for the namesake part of Hegel's system. A thorough understanding of the unity of Kant's Anthropology and a careful re-evaluation of its second part, the Anthropological characteristic, are capital steps in this process. I do believe that a renewed appreciation of Kant's role should imply no downgrading of Aristotle.

19 G. F. Meier, Auszug aus der Vernunftlehre, Halle 1752, §§ 529-531.

20 A. Sell, „Der Character bei Hegel und Kant - eine vergleichende Betrachtung,“ in: Hegel-Jahrbuch 2015 (2015), 161-166 (166).

21 Williams in: Hegel, Lectures on the Philosophy of Spirit 1827-1828, 4. 


\footnotetext{
Riccardo Martinelli University of Trieste Androna Campo Marzio, 10

I-34123 Trieste

martinel@units.it
} 